\title{
Factors affecting competence in a high frequency of transformation marine Vibrio
}

\author{
Marc E. Frischer, Jennifer M. Thurmond and John H. Paul* \\ Department of Marine Science, University of South Florida, 140 7th Avenue South, St Petersburg, \\ Florida 33701, USA
}

(Received 18 August 1992; revised 10 December 1992; accepted 18 December 1992)

\begin{abstract}
Natural plasmid transformation may be a mechanism for the horizontal transfer of non-conjugative plasmids in the marine environment, yet there are few marine model systems available for the study of this process. Using multimers of IncQ/P4 plasmids and a filter transformation assay, we have measured the effects of nutrients, salinity, temperature, as well as the development and maintenance of competence for genetic transformation in the high frequency of transformation (HFT) marine Vibrio strain WJT-1C. Transformation frequency was proportional to the amount of DNA used from 0.1 to $1.0 \mu \mathrm{g}$ DNA and was saturated at concentrations greater than 1.0 $\mu \mathrm{g}$. Competence began in the early-exponential phase and reached a maximum at the onset of stationary phase. Once attained, competence was maintained in both spent and nutrient-free media for at least $10 \mathrm{~d}$. Thus, the establishment and maintenance of competence was unique compared to previously described transformation systems. Temperatures ranging from 4 to $33{ }^{\circ} \mathrm{C}$ had no significant effect on the maximal transformation frequency of WJT-1C, but at $37^{\circ} \mathrm{C}$ the transformation frequency was reduced. However, temperature did affect the rate of the transformation process. Salinities in the range 12 to $50 \%$ had no significant effect on the transformation frequency but transformation frequencies were lower at $6 \%$ and $63 \%$. Cells were transformed equally well in nutrient-free media or rich media. The ability of this marine HFT Vibrio strain to develop competence under a wide spectrum of conditions and to maintain the competent state indicates that natural plasmid transformation could occur in conditions found in tropical and subtropical estuaries.
\end{abstract}

\section{Introduction}

During the last two decades a considerable amount of evidence has been collected indicating that prokaryotic gene exchange is an important microbial process in aquatic and terrestrial environments. The potential for genetic exchange by conjugation, transduction and natural transformation has been demonstrated in a variety of diverse environments (Graham \& Istock, 1978; Trevors \& Oddie, 1986; Bale et al., 1987, 1988; Rochelle et al., 1988; VanElsas et al., 1989; Fry \& Day, 1990; Henschke \& Schmidt, 1990; Paul et al., 1991; PretoriusGuth, 1990; Saye et al., 1990; Stewart \& Sinigalliano, 1990; Klingmuller, 1991). The occurrence of horizontal gene transfer events has been inferred by examining the

\footnotetext{
*Author for correspondence. Tel. (813) 893 9130; fax (813) 893
} 9189.

\footnotetext{
Abbreviations: DAPI, 4',6-diamidino-2-phenylindole; HFT, high
} frequency of transformation. distribution and genetic structure of specific phenotypes (e.g. streptomycin resistance) in natural microbial populations (Norelli et al., 1991; Smith et al., 1991). Additionally, gene transfer events from defined donors to indigenous microbial populations in a variety of environmental simulations have been documented (Henschke \& Schmidt, 1990; Stewart \& Sinigalliano, 1990; Fulthorpe \& Wyndham, 1991; Smit et al., 1991).

Natural transformation as a mechanism of genetic transfer in marine environments has not been extensively studied. Transformation is the process by which cells take up and express genes encoded by extracellular DNA (Avery et al., 1944). Natural transformation is distinct from artificial transformation (a widely used technique in molecular biology for the induction of competence in cells by chemical, enzymic or physical means) as being a normal physiological property of certain bacterial species (Smith et al., 1981; Saunders \& Saunders, 1988; Stewart, 1989). The presence of high-molecular-mass extracellular DNA (DeFlaun et al., 1987; Paul et al., 1987) and competent bacterial strains (Jeffrey et al., 1990; Rochelle 
et al., 1988; Saunders \& Saunders, 1988) suggests that this process can occur in aquatic environments.

The transfer of plasmids amongst natural bacterial populations in the environment is of special interest since plasmids may increase the metabolic potential of the indigenous flora (Novick, 1969; Broda, 1979; Foster, 1983; Schutt, 1990). Although the transfer of plasmids amongst bacterial communities is most often associated with conjugation, plasmid transfer can also be accomplished by transformation. Fry \& Day (1990) found that $65 \%$ of endogenously isolated plasmids from the River Taff, Wales, were less than $10 \mathrm{~kb}$, and therefore too small to encode conjugation genes. Furthermore, one of these small plasmids (pQM17; 7.8 kb), which encoded mercury resistance, could be transferred by natural transformation between Acinetobacter strains (Rochelle et al., 1988). Thus, transformation may be a mechanism responsible for the dissemination of small plasmids in aquatic environments.

Few studies have investigated the transformation process in marine organisms. The most extensive transformation studies have focused on three genera, Streptococcus, Haemophilus and Bacillus, and two transformation models have been developed based on these organisms (Smith et al., 1981; Stewart, 1989). However, other organisms seem to vary appreciably from these models (Stewart, 1989). Therefore, in order to understand natural transformation as a genetic exchange mechanism in marine environments, it is necessary to develop a model for natural transformation employing a marine micro-organism.

Recently we have described high frequency of transformation (HFT) marine Vibrio strains which can be transformed by plasmid DNA (Jeffrey et al., 1990; Frischer et al., 1990; Paul et al., 1991, 1992). In these investigations we have continued to develop these strains as transformation models to help understand the process of gene transfer in the marine environment.

\section{Methods}

Strains and plasmids. Bacterial strains and plasmids used as transforming DNA are listed in Table 1. The HFT Vibrio strain WJT1C (Frischer et al., 1990) was used as the recipient in all studies. The IncQ/P4 broad-host-range non-conjugative plasmids RSF1010, R1162 and pQSR50 were examined for their transforming activity and compared to the previously measured transforming activity of another IncQ/P4 plasmid, pGQ3 (Frischer et al., 1990). RSF1010 and R1162 are believed to be identical (Frey \& Bagdasarian, 1989). pGQ3 is a $13.5 \mathrm{~kb}$ derivative of pKT230 (an RSF1010 derivative) that contains the Escherichia coli thymidine kinase gene (Carlson et al., 1985). pQSR50 is a $14.4 \mathrm{~kb}$, Tn5-containing derivative of the plasmid R1162 (Meyer et al., 1982). After initial experiments the plasmid pQSR50 was chosen for all following investigations.

Culture conditions. In all experiments, Vibrio strain WJT-1C was grown in artificial seawater (ASWJP; Paul, 1982) supplemented with peptone and yeast extract (PY; Difco) at $29^{\circ} \mathrm{C}$ except where noted.
Unless otherwise specified the concentrations of peptone and yeast were 5 and $1 \mathrm{~g} \mathrm{l}^{-1}$, respectively. E. coli strains were grown at $37^{\circ} \mathrm{C}$ in LB (Sambrook et al., 1989) containing appropriate antibiotics.

Preparation of plasmids as transforming DNA. Plasmid DNA was purified by alkaline lysis as described by Griffith (1988) and further purified by use of a pZ523 plasmid purification column $\left(5^{\prime} \rightarrow 3^{\prime}\right.$ Inc., West Chester, PA, USA) (Felsenstein, 1988; Zervos et al., 1988). Plasmid preparations enriched in linear or oligomer forms were prepared by cutting to completion at a unique restriction site or by restriction digestion followed by ligation with $\mathrm{T} 4$ ligase, respectively (Jeffrey et al., 1990; Frischer et al., 1990). Oligomerization was judged by visualization on a $0.4 \%(\mathrm{w} / \mathrm{v})$ agarose gel stained with the fluorochrome Hoechst 33258 (DeFlaun \& Paul, 1986) as previously described (Frischer et al., 1990).

Transformation assays. The standard filter transformation assay was performed essentially as previously described except that stationaryphase (16-20 h growth period) cells were used, unless noted otherwise (Jeffrey et al., 1990; Frischer et al., 1990). Transformants were enumerated on ASWJP + PY plates containing kanamycin $\left(500 \mu \mathrm{g} \mathrm{ml}^{-1}\right)$ and streptomycin $\left(1000 \mu \mathrm{g} \mathrm{ml}^{-1}\right)$. Transformation frequency is reported as the number of antibiotic-resistant c.f.u. per total c.f.u. Where specified, transformation was inhibited by the addition of 100 Kunitz of DNAase I in $4.2 \mathrm{~mm}-\mathrm{MgCl}_{2}$ to filtered cells. All antibiotics and DNAase I were purchased from Sigma.

To determine the time required for transformation, $1 \mathrm{ml}$ of a stationary-phase culture of Vibrio WJT-1C (approximately $10^{9}$ cells) was immobilized onto a $0.2 \mu \mathrm{m}$ Nuclepore filter and overlaid with $4 \mu \mathrm{g}$ of transforming DNA as in the standard transformation assay, but at appropriate intervals DNAase I was added to inhibit further transformation.

To investigate the development of competence, early-exponentialphase cultures were used to inoculate fresh media and transformation was assayed as a function of growth phase using the standard assay. Growth was determined by measuring the optical density of the culture at $600 \mathrm{~nm}$. Transformation was determined at discrete growth phases by exposing cells to transforming DNA for $2 \mathrm{~h}$, after which DNAase I was added to the filter. To determine whether transformation was completely inhibited by the DNAase treatment, DNAase was added immediately following addition of transforming DNA to replica treatments. In these controls, no transformants were ever detected. The approximate concentration of cells was $10^{9}$ cells per filter.

The maintenance of competence in spent media was investigated by allowing a culture of WJT-1C to incubate shaking at $29^{\circ} \mathrm{C}$ for $10 \mathrm{~d}$. Competence maintenance under starvation conditions was also determined by incubating washed cells in ASWJP without nutrients under the same conditions for $10 \mathrm{~d}$. In the latter studies the concentration of the culture was maintained at low cell densities (approx. $10^{6}$ cells $\mathrm{ml}^{-1}$ ) to simulate naturally occurring bacterial densities and to prevent nutrient scavenging. In both conditions (i.e. spent or starvation media), the culture was sampled daily for $5 \mathrm{~d}$ and again after $10 \mathrm{~d}$. Viable counts (total c.f.u. $\mathrm{ml}^{-1}$ ), direct cell counts and the transformation frequency were determined at all sampling times.

To investigate the effect of temperature on the transformation frequency, cultures of WJT-1C were grown to late-exponential phase $\left(\mathrm{OD}_{600} 0 \cdot 8\right)$ at temperatures ranging from 15 to $37^{\circ} \mathrm{C}$ and transformed at the same temperatures as used for growth. For transformation assays at $4{ }^{\circ} \mathrm{C}$, cells were grown at $15^{\circ} \mathrm{C}$ and then transferred to $4{ }^{\circ} \mathrm{C}$ after being filtered.

To determine the effect of salinity, media of various salinities were prepared by dilution of double-strength artificial seawater $(2 \times$ ASWJP) with deionized water. The lowest-salinity medium $(6 \%)$ was prepared by adding PY to deionized water. Cultures of WJT-1C were then grown and transformed using the standard filter assay at salinities ranging from 6 to $63 \%$. 
Table 1. Bacteria and plasmids

\begin{tabular}{|c|c|c|}
\hline Strain or plasmid & Phenotype or description & Source or reference \\
\hline \multicolumn{3}{|l|}{ Strains } \\
\hline Vibrio WJT-1C & $\begin{array}{l}\text { HFT derivative of estuarine isolate } \\
\text { DI-9 }\end{array}$ & Frischer et al. (1990) \\
\hline E. coli RM1208(R1162) & $\mathrm{F}^{-}$thi lacY thr leuB supE44 $\Delta \operatorname{trp} E 5$ & Meyer et al. (1982) \\
\hline E. coli $\mathrm{RM} 1259$ (pQSR50) & $\mathrm{F}^{-}$thi lacY thr leuB supE44 $\triangle$ trpE5 & Meyer et al. (1982) \\
\hline E. coli JL3700(RSF1010) & $\begin{array}{l}\mathrm{F}^{-} \text {gal thi fhuA endA sbcB15 hsdR4 } \\
\text { shdM }\end{array}$ & Gift of G. Stewart, Univ. S. Florida, Tampa \\
\hline E. coli JL4062(pGQ3) & HB101 & Carlson et al. (1985) \\
\hline \multicolumn{3}{|l|}{ Plasmids } \\
\hline R1162 & IncQ/P-4 Sur $\mathrm{Sm}^{\mathrm{r}} \mathrm{Mob}^{+}$ & Meyer et al. (1982) \\
\hline RSF 1010 & IncQ/P-4 Su${ }^{\mathrm{r}} \mathrm{Sm}^{\mathrm{r}} \mathrm{Mob}^{+}$ & Frey \& Bagdasarian (1989) \\
\hline pQSR50 (= R1162::Tn5) & IncQ/P-4 Su ${ }^{r} \mathrm{Sm}^{\mathrm{r}} \mathrm{Km}^{\mathrm{r}} \mathrm{Mob}^{+}$ & Meyer et al. (1982) \\
\hline pGQ3 & IncQ/P-4 Su ${ }^{r} \mathrm{Sm}^{\mathrm{r}} \mathrm{Km}^{\mathrm{r}} \mathrm{tdk}^{+} \mathrm{Mob}^{+}$ & Carlson et al. (1985) \\
\hline
\end{tabular}

The effect of nutrient concentration on transformation was evaluated with the standard assay by growing and transforming cells at nutrient concentrations ranging from ASWJP $+1 \%(\mathrm{w} / \mathrm{v}) \mathrm{PY}(0.05 \mathrm{~g} \mathrm{P}$ and $\left.0.01 \mathrm{~g} \mathrm{Y}^{-1}\right)$ to ASWJP $+200 \%(\mathrm{w} / \mathrm{v})$ PY $\left(10 \mathrm{~g} \mathrm{P}\right.$ and $\left.2 \mathrm{~g} \mathrm{Y} \mathrm{l}^{-1}\right)$.

\section{Results}

\section{Transforming plasmid DNA}

Table 2 shows the results of transformation of the HFT Vibrio strain WJT-1C with multimers of four nonconjugative broad-host-range IncQ/P4 plasmids. Multimers of the plasmids RSF1010 and R1162 yielded the highest transformation frequencies, from 4.5 to $9 \cdot 1 \times 10^{-3}$ transformants per recipient. Transformation of WJT-1C with pQSR50 multimers resulted in transformation frequencies approximately two orders of magnitude lower than did RSF1010 and R1162. pGQ3 multimers had the lowest transforming activity, approximately three orders of magnitude lower than that of $\mathrm{PQSR}$ 50. Transformation frequencies were compared by analysis of variance and multiple-range testing (Zar, 1984). It was concluded that multimers of RSF1010 and R1162 had identical transforming activities, while pGQ3

Table 2. Transformation frequency of WJT-1C with Inc $Q / P 4$ plasmids

\begin{tabular}{llcc}
\hline \hline Plasmid & $\begin{array}{c}\text { Selected } \\
\text { markers* }\end{array}$ & $\begin{array}{c}\text { Transformation } \\
\text { frequency }( \pm \text { SD }) \dagger\end{array}$ & $\begin{array}{c}\text { No. of } \\
\text { trials }\end{array}$ \\
\hline RSF1010 & Sm & $9 \cdot 1(2 \cdot 2) \times 10^{-3 a}$ & 7 \\
R1162 & Sm & $4 \cdot 5(1 \cdot 8) \times 10^{-3 a}$ & 4 \\
pQSR50 & Km, Sm & $5 \cdot 5(3 \cdot 9) \times 10^{-5 b}$ & 19 \\
pGQ3 & Km, Sm & $4 \cdot 4(3 \cdot 2) \times 10^{-8 c}$ & 2 \\
\hline \hline
\end{tabular}

${ }^{*} \mathrm{Km}$, kanamycin; Sm, streptomycin.

$\dagger a$, indicates results that are statistically identical $(P>0.5) ; b$, indicates significant difference from the transformation frequency of RSF1010 and pGQ3 $(0.01<P<0.001) ; c$, indicates significant difference from the transformation frequency of RSF 1010 and PQSR50 $(0.05<P<0.01)$.

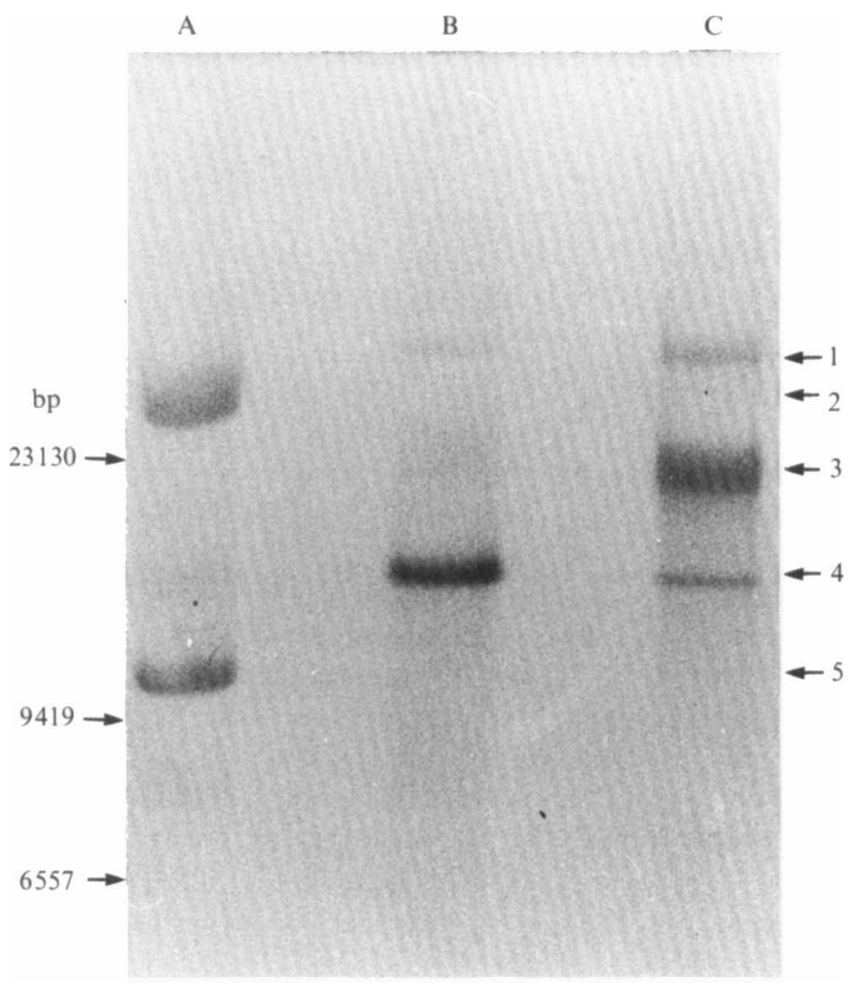

Fig. 1. Autoradiograph of a Southern transfer of pQSR50 plasmid preparations hybridized with ${ }^{35} \mathrm{~S}$-labelled Riboprobe RNA probe pNPTII. A, untreated plasmid preparation; B, linear enrichment; C, oligomer enrichment. Bands 1-5, marked on the autoradiograph, correspond to: (1) linear dimer, (2) covalently closed relaxed monomer, (3) covalently closed oligomer, (4) linear, and (5) covalently closed supercoiled monomer forms of pQSR50. Positions of molecular size markers (HindIII-digested $\lambda$ phage DNA) are indicated.

and pQSR50 had significantly different transforming activities, both from RSF1010 and R1162 as well as from each other (Table 2).

Although the plasmids R1162 and RSF1010 yielded the highest transformation frequencies, spontaneous 


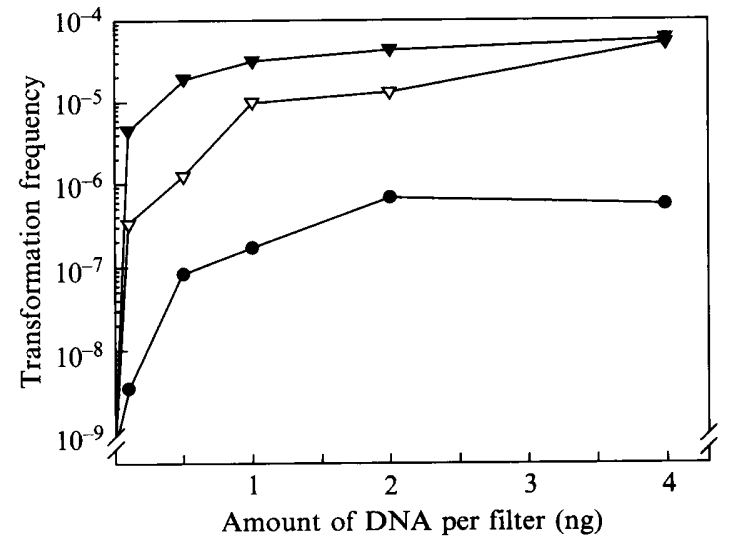

Fig. 2. Transformation frequency as a function of the amount of plasmid DNA per filter using an untreated plasmid preparation $(\nabla)$, a unique site restriction enzyme digested plasmid preparation $(\bullet)$ or a plasmid preparation enriched for oligomers $(\boldsymbol{\nabla})$.

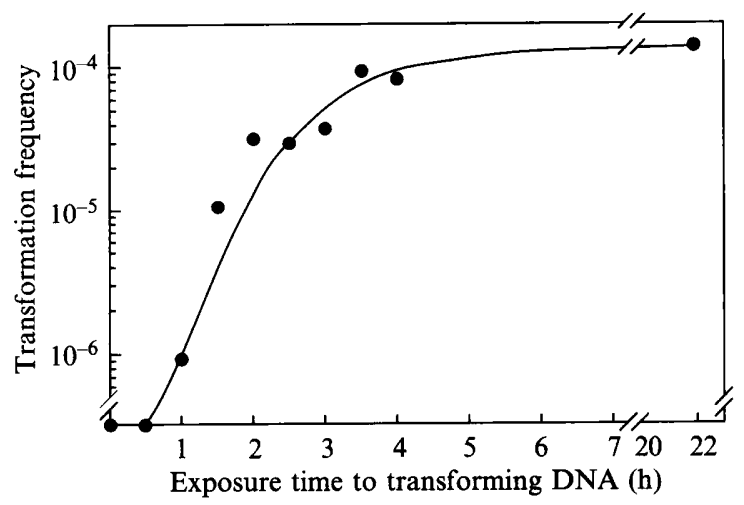

Fig. 3. Transformation of Vibrio strain WJT-1C as a function of length of time of exposure to pQSR50 DNA.

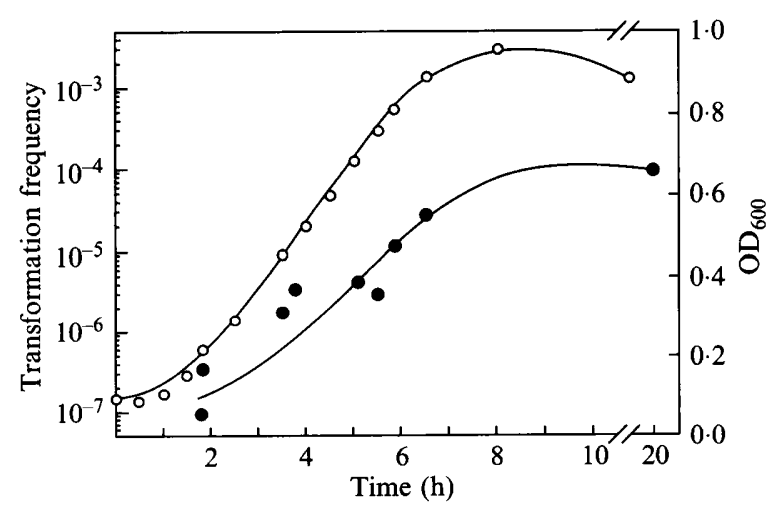

Fig. 4. Development of competence in Vibrio strain WJT-1C. Transformation frequency; $\mathrm{O}$, growth of culture $\left(\mathrm{OD}_{600}\right)$.

resistance to streptomycin occurred in WJT-1C at a frequency of $3.1 \times 10^{-7}$. Therefore, we chose to use pQSR50 as transforming DNA in all following investigations since the rate of spontaneous mutation to WJT-1C to both streptomycin and kanamycin was below $10^{-9}$ (data not shown).

\section{Concentration and form of transforming plasmid DNA}

The amount of plasmid DNA required for transformation of WJT-1C and the relationship between the transforming activity of an untreated plasmid preparation to those which had been enriched for either linear or oligomeric forms was investigated. Fig. 1 shows an autoradiograph of a Southern blot (Sambrook et al., 1989) of the plasmid preparations used. Filters were hybridized to the ${ }^{35} \mathrm{~S}$-labelled probe pNPTII, which hybridizes to the neomycin phosphotransferase gene of Tn5 contained on pQSR50 (Frischer et al., 1990). None of the preparations were composed solely of one topological form. The untreated plasmid preparation (lane A) was composed primarily of relaxed (band 2) and supercoiled (band 5) forms. These two forms were distinguished from each other by a topoisomerase assay (data not shown) preformed as recommended by the manufacturer (Promega Corporation). Preparation B was composed primarily of linearized pQRS50 (band 4) but also contained a trace amount of what appeared to be linearized dimeric molecules, based on its molecular size (band 1). Preparation C was composed primarily of covalently closed oligomeric molecules (band 3 ) but also contained linear monomer and dimer molecules. The transformation activity of each of these plasmid preparations was assayed. Transformation was observed in all preparations and increased exponentially with concentration until saturation at $1.0 \mu \mathrm{g}$ DNA per filter (Fig. 2). Transformation was observed at the lowest concentrations of DNA tested (100 ng per filter or approx. $0.1 \mathrm{fg}$ per cell), even in the digested preparation. Below saturating concentrations, preparations enriched in oligomeric molecules exhibited higher transforming activity than did the untreated preparation. At all concentrations tested the plasmid preparation enriched for linear molecules (preparation B) had the lowest transforming activity.

\section{Time required for transformation}

Fig. 3 shows the transformation of Vibrio strain WJT-1C exposed to pQSR50 multimers as a function of time. Transformants were detected after $1 \mathrm{~h}$ of exposure $\left(9 \cdot 2 \times 10^{-7}\right.$ transformants per recipient), but were not detected when the exposure period was limited to $30 \mathrm{~min}$. The transformation frequency increased exponentially from $1 \mathrm{~h}$ to $4 \mathrm{~h}$, at which point the transformation frequency was $8.3 \times 10^{-5}$ transformants per recipient. The transformation frequency was only slightly increased by continuing exposure overnight $\left(22 \mathrm{~h} ; 1.4 \times 10^{-4}\right.$ transformants per recipient). Because these incubations were terminated by DNAase I treatment these results indicate that at least the binding and uptake of transforming DNA resulting in a DNAase I protected 


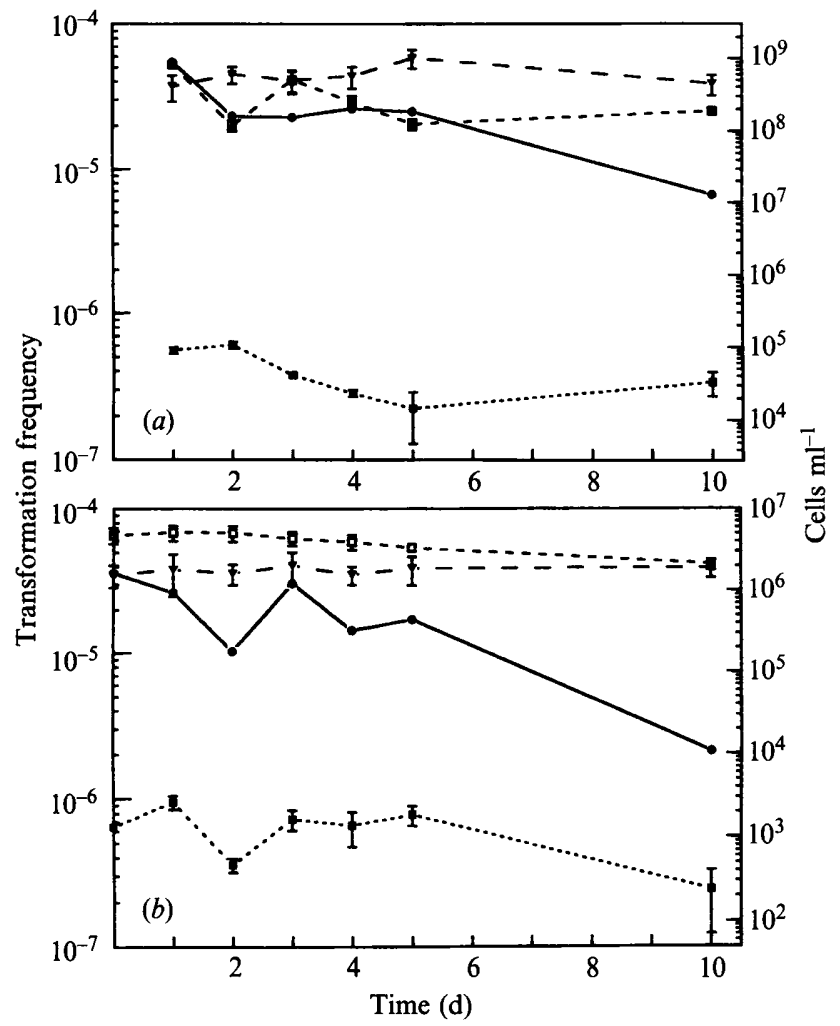

Fig. 5. Maintenance of competence in Vibrio strain WJT-1C in (a) artificial seawater with nutrients $\left(5 \mathrm{~g}\right.$ peptone and $1 \mathrm{~g}$ yeast extract $\left.\mathrm{l}^{-1}\right)$ and in $(b)$ artificial seawater without nutrients. -0 , Transformation frequency; $\mathbf{\square} \cdots \mathbf{\square}$, transformants $\mathrm{ml}^{-1} ; \nabla--\nabla$, total c.f.u.; $\square---\square$, DAPI direct counts. Bars indicate SD for cells $\mathrm{ml}^{-1}$ determinations (not shown where smaller than symbol).

condition occurs within this time period, similar to the transformation process in other organisms (Contente \& Dubnau, 1978; Albano et al., 1987; Seifert et al., 1988).

\section{Development of competence}

Fig. 4 shows the onset of competence in Vibrio strain WJT-1C. Transformation could be detected at the earliest growth phase assayed (early exponential) and it increased exponentially from $3.5 \times 10^{-7}$ transformants per recipient in the early-exponential phase to $2.8 \times 10^{-5}$ transformants per recipient in the late-exponential phase. Maximal transformation frequencies occurred during the stationary phase $\left(1.8 \times 10^{-5}\right.$ transformants per recipient).

\section{Maintenance of the competent state}

Fig. 5 shows the maintenance of competence in cultures of Vibrio strain WJT-1C which were kept for up to $10 \mathrm{~d}$ in spent rich medium (Fig. $5 a$ ) or in starvation medium (Fig. 5b). Total viable counts, DAPI direct counts, transformants $\mathrm{ml}^{-1}$, and transformation frequency were
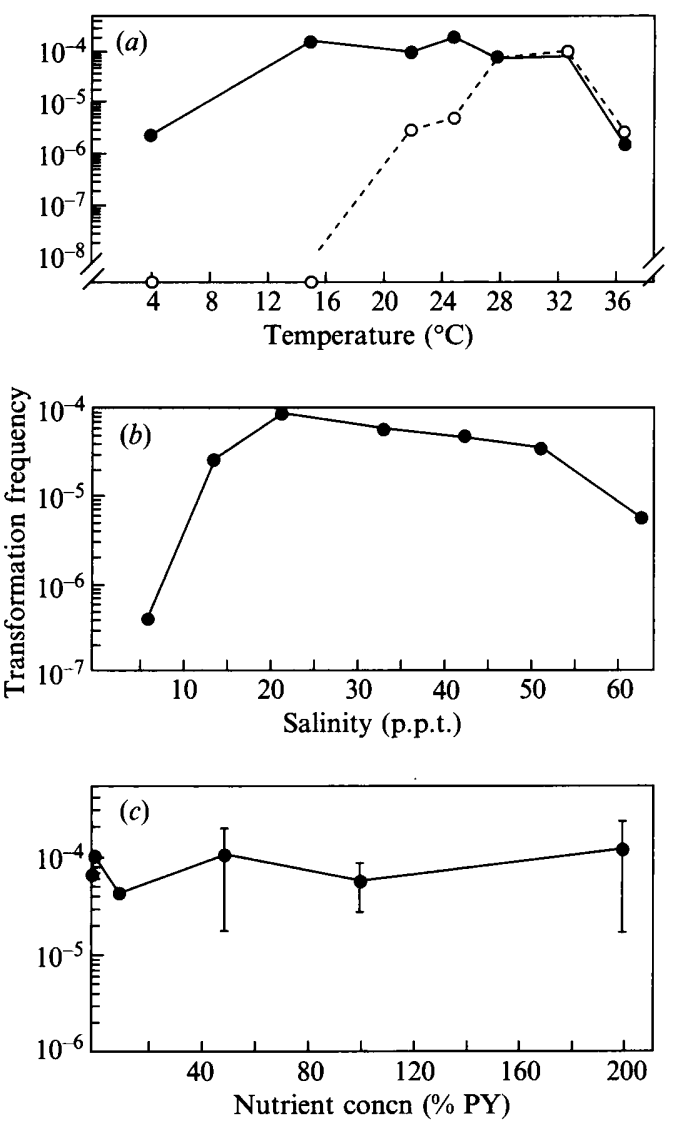

Fig. 6. Effect of temperature, salinity and nutrient concentration on the competence of Vibrio strain WJT-1C. (a) Effect of temperature. $\mathrm{O}--\mathrm{O}$, Transformation frequency determined after $4 \mathrm{~h}$ exposure to plasmid DNA; - after $20 \mathrm{~h}$ exposure to plasmid DNA. (b) Effect of salinity. $(c)$ Effect of nutrient concentration. Nutrient concentration expressed as a percentage of the standard peptone $(P)$ and yeast extract (Y) concentration $\left(100 \% \mathrm{PY}=5 \mathrm{~g} \mathrm{P}, 1 \mathrm{~g} \mathrm{Y} \mathrm{I}^{-1}\right)$. Bars in $(c)$ indicate SD (not shown where smaller than symbol).

measured over the incubation period. Competence was maintained at high levels in both spent and nutrient-free media for the $10 \mathrm{~d}$ duration of the experiments. In spent nutrient medium, transformation frequency decreased from $5 \cdot 5 \times 10^{-5}$ to $6 \cdot 6 \times 10^{-6}$ transformants per recipient over the $10 \mathrm{~d}$ period, while in nutrient-free medium the transformation frequency decreased from $3.59 \times 10^{-5}$ to $2 \cdot 1 \times 10^{-6}$ transformants per recipient over the same time period. In both cultures total viable counts, direct counts, and the number of transformants $\mathrm{ml}^{-1}$ remained relatively unchanged during the $10 \mathrm{~d}$ incubations. These results indicate that competence is maintained at relatively high levels despite a lack of growth.

\section{Effect of temperature}

Fig. 6(a) shows the effect of temperature on competence of Vibrio strain WJT-1C after 4 or $20 \mathrm{~h}$ exposure to plasmid DNA. WJT-1C can grow at temperatures up to 
$39^{\circ} \mathrm{C}$, with fastest growth rates around $37^{\circ} \mathrm{C}$ (data not shown). From 15 to $33^{\circ} \mathrm{C}$, temperature had little effect on the maximum transformation frequency when this was measured after $20 \mathrm{~h}$ of exposure, but transformation frequencies measured after $4 \mathrm{~h}$ increased with temperature in this range. After $4 \mathrm{~h}$ of exposure, transformants could not be detected at either 4 or $15^{\circ} \mathrm{C}$. At $37^{\circ} \mathrm{C}$ the maximal transformation frequency was significantly lower $\left(1.5 \pm 0.01 \times 10^{-6}\right.$ transformants per recipient) compared to maximal transformation frequencies at $29^{\circ} \mathrm{C}$ $\left(7.5 \pm 4.7 \times 10^{-5}\right.$ transformants per recipient). This was true whether exposure to DNA was for $4 \mathrm{~h}$ or for $20 \mathrm{~h}$. At $37^{\circ} \mathrm{C}$, competence development was equivalent to that at $29^{\circ} \mathrm{C}$, but transformation frequencies were approximately 100 -fold lower during all growth phases (data not shown).

\section{Effect of salinity}

Fig. $6(b)$ shows the effect of salinities ranging from $6 \%$ to $63 \%$ on the competence of WJT-1C. Transformants were detected at all salinities, with lowest transformation frequencies at $6 \%\left(3.9 \times 10^{-7}\right.$ transformants per recipient) and highest at $22 \%\left(8.4 \times 10^{-5}\right.$ transformants per recipient). From 22 to $51 \%$ there was a small decrease in transformation efficiency to $3.2 \times 10^{-5}$, and there was a further decrease to $4.85 \times 10^{-6}$ transformants per recipient at $63 \%$.

\section{Effect of nutrients}

Nutrient concentrations ranging from $1 \%$ to $200 \%$ of standard PY concentration had no significant effect on the frequency of transformation (Fig. 6c), although higher nutrient levels stimulated the growth of both transformants and non-transformants (data not shown).

\section{Discussion}

The induction and maintenance of a competent state are important both for the comparison of the HFT model to other transformation models and to determine favourable conditions for natural transformation in the environment. The development of competence in the HFT Vibrio began during early-exponential phase, and once attained was maintained for at least $10 \mathrm{~d}$. Furthermore, competence was unaffected by starvation conditions and could only be reduced by allowing the cells to return to exponential growth. This pattern is in contrast to competence development patterns in other transformation models. Competence in most other organisms appears to be a tightly regulated process, occurring only during late-exponential or stationary phase for a short period of time, after which competence declines dramatically (Smith et al., 1981; Stewart \&
Carlson, 1986; Stewart, 1989). Exceptions include Streptococcus pneumoniae, in which a low level of competence develops in mid-exponential-phase cultures but is not maintained after maximal competence is achieved in lateexponential phase (Pakula \& Walczak, 1963; Tomaz \& Hotchkiss, 1964), and Neisseria, in which competence is constitutive in piliated strains (Sparling, 1966). Competence in Acinetobacter calcoaceticus strains derived from strain BD413 (Juni, 1972) has recently been shown to be constitutively expressed, but competence in this strain declined rapidly during $30 \mathrm{~h}$ incubation in sterile river water (H. G. Williams, M. J. Day, J. C. Fry \& G. J. Stewart, unpublished results). This work was in contrast with earlier work with $A$. calcoaceticus strains BD413 and NCIB 8250 , in which competence was found only during the mid-exponential growth phase (Ahlquist et al., 1980; Cruze et al., 1979). Thus, the HFT Vibrio WJT1C seems to be unique with respect to competence development and maintenance.

Mutants of Haemophilus influenzae and S. pneumoniae have been isolated which exhibit enhanced competence (Redfield, 1991; Lacks \& Greenberg, 1973). However, the similarity of these mutations to the HFT mutation is unclear since HFT strains seem not only to exhibit enhanced competence during early-exponential phase but also during stationary phase (Frischer et al., 1990). Additional investigations are required to determine the nature of these mutations in $H$. influenzae, S. pneumoniae, and in Vibrio. It may be that these marine Vibrio HFT strains do not possess transformation systems that are under the control of a specific regulon. Rather, a mutation in any number of cellular functions (e.g. membrane permeability, macromolecular transport, nuclease activities, or any DNA-processing function) may give rise to the competent phenotype. If this is the case then the establishment of heterologous DNA by transformation may be more common then is indicated by the rarity of competent organisms, especially if plasmids which provide selective advantages are involved.

The effects of temperature, salinity, and nutrient concentration on plasmid transformation frequency in Vibrio strain WJT-1C were minimal. Significant reduction from the maximal transformation frequency was observed only in conditions that rarely occur in estuarine environments. This observation suggests that estuarine environments provide conditions which facilitate plasmid transformation. Similar conclusions have been reached concerning the process of conjugation in environmental isolates (Rochelle et al., 1989; Sambri \& Lovett, 1989). The stability of transformation frequency over a wide temperature range indicates that the transformation process is independent of the growth rate, substantiating the observation that transformation occurs normally 
during periods of unbalanced or stationary growth. Interestingly, competence was significantly reduced at $37^{\circ} \mathrm{C}$. Cells which were grown and transformed in a variety of different salinities $(12-50 \%$ ) exhibited only small differences in transformation frequencies, demonstrating that transformation of this organism could occur equally efficiently under the wide range of salinities that might normally be encountered by this organism. As with temperature and salinity, the concentration of nutrients in the growth media had little effect on the transformation frequency of WJT-1C, although the nutrient level greatly affected the culture yields. The pattern of competence development and the flexibility in culture conditions which support transformation suggests that HFT marine Vibrio strains could readily acquire plasmids via natural transformation under a variety of circumstances, especially during starvation or even during the seemingly dormant physiological state termed the 'starvation state' (Morita, 1985).

Plasmid oligomers were used in these studies as transforming DNA because they contain self-homology, believed to be required for homologous recombination (Stewart, 1989; Saunders \& Saunders, 1988). Enrichment for oligomers in the plasmid preparations increased the transforming activity, suggesting that, as in other transformation systems, homologous recombination facilitates plasmid establishment in HFT marine Vibrio strains. Regardless of the plasmid preparation used, the transformation frequency was dependent on the amount of DNA available and the process could be saturated, possibly indicating the existence of DNA-binding sites. Alternatively, saturation may be an artifact of the assay, which probably limits transformation to organisms on the surface of the cell spot.

A critical question concerning the potential for natural transformation as a route of gene exchange in the marine environment is whether there are sufficient concentrations of dissolved DNA in marine environments to act as transforming DNA. The results from this study demonstrated transformation even at the lowest DNA concentrations used (100 ng per filter; $10^{9}$ cells per filter). This concentration is within the range of DNA concentrations reported for marine environments (DeFlaun et al., 1987; Ogram et al., 1987). However, it is difficult to extrapolate these results to the natural environment since there are no estimates of the fraction of dissolved DNA that represents DNA with transforming potential and only a few estimates of the fraction of marine bacteria that are competent for natural transformation (Stewart \& Cyr 1987; M. E. Frischer, unpublished results). Thus, the implications are that sufficient dissolved DNA concentrations for transformation exist in estuarine waters, but further characterization of dissolved DNA pools and competence in marine micro-organisms with marine plasmids will be necessary before we can better extrapolate our results to the marine environment.

Another important consideration concerning the potential for transformation in the environment is the comparison between the rate of degradation of DNA and the rate at which it can be taken up for transformation. The results presented in this work indicate that transformation, or at least the sequestering of transforming DNA into a DNAase-protected form, is rapid, occurring on a time scale of minutes to hours, while rates of DNA turnover in marine surface waters and sediments have been reported to be in the order of hours to days (DeFlaun \& Paul, 1989; Paul et al., 1987; Bazalyan \& Ayzatullin, 1979; Novitsky, 1986; Maeda \& Taga, 1974). Therefore it may be speculated that the turnover rate of DNA is not the primary limiting factor for transformation in marine environments and that depending on other parameters (e.g. cell density, DNA availability, presence of inhibitory agents) natural transformation may occur readily.

These studies indicate that the HFT marine Vibrio strain WJT-1C possesses transformation characteristics not observed in other transformation systems. The transformation system of this marine Vibrio enabled transformation to occur under highly variable conditions normally associated with natural environments. The ability of this strain to maintain a competent state for long periods and the speed at which it can sequester DNA support our earlier observations from microcosm studies that natural transformation could allow for the transfer of small plasmids in the marine environment.

This work was supported in part by a National Science Foundation grant OCE 8817172 and by the US EPA, contract no. R819413-01-0 to J.H.P. M.E.F. was supported by a John B. Lake Fellowship and a Gulf Coast Oceanographic Charitable Trust Fellowship. Further support was obtained from the Institute for Biomolecular Science and the Clearwater Power Squadron to M.E.F.

We also thank Ms Allison Gilbert for her technical assistance.

\section{References}

Ahlquist, E. F., Fewson, C. A., Podmore, J. \& Rowell, V. (1980). Competence for genetic transformation in Acinetobacter calcoaceticus NCIB8250. FEMS Microbiology Letters 7, 107-109.

Albano, M., Hahn, J. \& DubnaU, D. (1987). Expression of competence genes in Bacillus subtilis. Journal of Bacteriology 169, 3110-3117.

Avery, T., MacLeod, C. M. \& MCCarty, M. (1944). Studies on the chemical nature of the substance inducing transformation in pneumococcal types. Journal of Experimental Medicine 79, 137-159.

BALE, M. J., FRY, J. C. \& DAY, M. J. (1987). Plasmid transfer between strains of Pseudomonas aeruginosa on membrane filters attached to river stones. Journal of General Microbiology 133, 3099-3107.

Bale, M. J., FrY, J. C. \& DAY, M. J. (1988). Transfer and occurrence of large mercury resistance plasmids in river epilithon. Applied and Environmental Microbiology 54, 972-978.

Bazalyan, V. L. \& Ayzatullin, T. A. (1979). Kinetics of enzymatic hydrolysis of DNA in seawater. Oceanology 19, 30-33.

BrodA, P. (1979). Plasmids. Oxford: Freeman.

Carlson, C. A., Stewart, G. J. \& Ingraham, J. L. (1985). Thymidine 
salvage in Pseudomonas stutzeri and Pseudomonas aeruginosa provided by heterologous expression of Escherichia coli thymidine kinase gene. Journal of Bacteriology 163, 291-295.

Contente, S. \& DubNaU, D. (1979). Characterization of plasmid transformation in Bacillus subtilis: kinetic properties and the effect of DNA conformation. Molecular and General Genetics 167, 251-258.

Cruze, J. A., Singer, J. T. \& Finner Ty, W. R. (1979). Conditions for quantitative transformation in Acinetobacter calcoaceticus. Current Microbiology 3, 129-132.

DeFlaun, M. F. \& PaUl, J. H. (1986). Hoechst 33258 staining of DNA in agarose gel electrophoresis Journal of Microbiological Methods 5 , 265-270.

DeFlaun, M. F. \& Paul, J. H. (1989). Detection of exogenous gene sequences in dissolved DNA from aquatic environments. Microbial Ecology 18, 21-28.

DeFlaun, M. F., Paul, J. H. \& Jefrrey, W. H. (1987). Distribution and molecular weight of dissolved DNA in subtropical estuarine and oceanic environments. Marine Ecology Progress Series 38, 65-73.

Felsenstern, K. M. (1988). A modified protocol for the pZ523 columns : a legitimate alternative for plasmid DNA. BioTechniques 6, 847-848.

FosTER, T. S. (1983). Plasmid-determined resistance to antibiotics and toxic heavy metal ions in bacteria. Microbiological Reviews 47, $361-409$.

Frey, J. \& Bagdasarian, M. (1989). The molecular biology of IncQ plasmids. In Promiscuous Plasmids of Gram-negative Bacteria, pp. 79-94. Edited by C. M. Thomas. London: Academic Press.

Frischer, M. E., Thurmond, J. M. \& Paul, J. H. (1990). Natural plasmid transformation in a high-frequency-of-transformation marine Vibrio strain. Applied and Environmental Microbiology 56, 3439-3444.

FRY, J. C. \& DAY, M. J. (1990). Plasmid transfer in the epilithon. In Bacterial Genetics in Natural Environments, pp. 55-80. Edited by J. C. Fry \& M. J. Day. London: Chapman \& Hall.

Fulthorpe, R. R. \& WyndhaM, R. C. (1991). Transfer and expression of the catabolic plasmid pBRC60 in wild bacterial recipients in a freshwater ecosystem. Applied and Environmental Microbiology 57, $1546-1553$

Graham, B. J. \& Istock, C. A. (1978). Genetic exchange in Bacillus subtillis in soil. Molecular and General Genetics 166, 287-290.

GRIFFITH, O. M. (1988). Large-scale isolation of plasmid DNA using high speed centrifugation methods. BioTechniques 6, 725-727.

HeNSCHKE, R. B. \& SCHMidT, F. R. J. (1990). Plasmid mobilization from genetically engineered bacteria to members of the indigenous soil microflora in situ. Current Microbiology 20, 105-110.

Jefrerey, W. H., Paul, J. H. \& Stewart, G. J. (1990). Natural transformation of a marine Vibrio species by plasmid DNA. Microbial Ecology 19, 259-269.

JUNI, E. (1972). Interspecies transformation of Acinetobacter: genetic evidence for a ubiquitous genus. Journal of Bacteriology 112, 917-931.

KLINGMULleR, W. (1991). Plasmid transfer in natural soil: a case by case study with nitrogen-fixing Enterobacter. FEMS Microbiology Ecology 85, 107-116.

LACKS, S. \& GREENBERG, B. (1973). Competence for deoxyribonucleic acid uptake and deoxyribonuclease action external to cells in the genetic transformation of Diplococcus pneumoniae. Journal of Bacteriology 114, 152-163.

MaEDA, M. \& TAGA, N. (1974). Occurrence and distribution of deoxyribonucleic acid hydrolyzing bacteria in seawater. Journal of Experimental Marine Biology and Ecology 14, 157-169.

Meyer, R., Laux, R., Boch, G., Hinds, M., Bayly, R. \& Shapiro, J. A. (1982). Broad-host range IncP-4 plasmid R1162: effects of deletions and insertions on plasmid maintenance and host range. Journal of Bacteriology 152, 140-150.

MoRITA, R. Y. (1985). Starvation and miniaturization of heterotrophs, with special emphasis on maintenance of the starved viable state. In Bacteria in Their Natural Environments, pp. 111-130. Edited by M. M. Fletcher \& G. D. Floodgate. London: Academic Press.

Norelli, J. L., Burr, T. J., Adriana, A. M., Cicero, L., Gilbert, M. T. \& KATZ, B. H. (1991). Homologous streptomycin resistance gene present among diverse Gram-negative bacteria in New York
State apple orchards. Applied and Environmental Microbiology 57, 486-491.

Novick, R. P. (1969). Extrachromosomal inheritance in bacteria. Bacteriological Reviews 33, 210-263.

Novitsky, J. A. (1986). Degradation of dead microbial biomass in a marine sediment. Applied and Environmental Microbiology 52, 504-508.

Ogram, A., SaYler, G. S. \& Barkay, T. (1987). The extraction and purification of microbial DNA from sediments. Journal of Microbiological Methods 7, 57-66.

PAKUla, R. \& WALCZAK, W. (1963). On the nature of competence of transformable streptococci. Journal of General Microbiology 31, $125-133$.

PaUl, J. H. (1982). The use of Hoechst dyes 33258 and 33342 for enumeration of attached and planktonic bacteria. Applied and Environmental Microbiology 43, 939-944.

Paul, J. H., Jeffrey, W. H. \& DeFlaun, M. F. (1987). Dynamics of extracellular DNA in the marine environment. Applied and Environmental Microbiology 53, 170-179.

Paul, J. H., Frischer, M. E. \& Thurmond, J. M. (1991). Gene transfer in marine water column and sediment microcosms by natural plasmid transformation. Applied and Environmental Microbiology 57, 1509-1515.

Paul, J. H., Thurmond, J. M., Frischer, M. E. \& Cannon, J. P. (1992). Intergeneric natural plasmid transformation between $E$. coli and a marine Vibrio species. Molecular Ecology 1, 37-46.

Pretorius-Guth, I. M., Puhler, A. \& Simon, R. (1990). Conjugal transfer of megaplasmid 2 between Rhizobium meliloti strains in alfalfa nodules. Applied and Environmental Microbiology 56, 2354-2359.

REDFIELD, R. J. (1991). sxy-1, a Haemophilus influenzae mutation causing greatly enhanced spontaneous competence. Journal of Bacteriology 173, 5612-5618.

Rochelle, P. A., DAY, M. J. \& FrY, J. C. (1988). Occurrence, transfer and mobilization in epilithic strains of Acinetobacter of mercuryresistance plasmids capable of transformation. Journal of General Microbiology 134, 2933-2941.

Rochelle, P. A., FrY, J. C. \& DAY, M. J. (1989). Factors affecting conjugal transfer of plasmids encoding mercury resistance from pure cultures and mixed natural suspensions of epilithic bacteria. Journal of General Microbiology 135, 409-424.

SAMBRI, B. \& LOVETT, M. A. (1989). Influence of several experimental parameters on inter- and intra-specific mating process efficiency. Microbiologica 12, 323-328.

Sambrook, J., Fritsch, E. F. \& Maniatis, T. (1989). Molecular Cloning, a Laboratory Manual, 2nd edn. Cold Spring Harbor, NY: Cold Spring Harbor Laboratory.

SAUNDERS, J. R. \& SAUNDERS, V. A. (1988). Bacterial transformation with plasmid DNA. Methods in Microbiology 21, 79-128.

Saye, D. J., Ogunseitan, O. A., Sayler, G. S. \& Miller, R. V. (1990). Transduction of linked chromosomal genes between Pseudomonas aeruginosa strains during incubation in situ in a freshwater habitat. Applied and Environmental Microbiology 56, 140-145.

ScHUTT C. (1990). Plasmids and their role in natural aquatic bacterial communities. In Aquatic Microbial Ecology: Biochemical and Molecular Approaches, pp. 160-183. Edited by G. Overbeck \& R. J. Chrost. New York: Springer-Verlag.

Seifert, H. S., Ajioka, R. S., Marchal, C., Sparling, P. F. \& MAGDALENE, So. (1988). DNA transformation leads to pilin antigenic variation in Neisseria gonorrhoeae. Nature, London 336, 392-395.

Smit, E., VanElsas, J. D., VanVeen, J. A. \& DeVos, W. M. (1991). Detection of plasmid transfer from Pseudomonas fuorescens to indigenous bacteria in soil using bacteriophage OR2 for donor counter selection. Applied and Environmental Microbiology 57, $3482-3488$.

Smith, H. O., Danner, D. B. \& Deich, R. A. (1981). Genetic transformation. Annual Review of Biochemistry 50, 140-145.

Smith, J. M., Dowson, C. J. \& SpRATT, B. G. (1991). Localized sex in bacteria. Nature, London 349, 29-31.

SPARLING, P. F. (1966). Genetic transformation of Neisseria gonorrhoeae to streptomycin resistance. Journal of Bacteriology 92, 1364-1371. 
STEWART, G. J. (1989). The mechanism of natural transformation. In Gene Transfer in the Environment, pp. 139-164. Edited by S. B. Levy \& R. V. Miller. New York: McGraw Hill.

StewarT, G. J. \& Carlson, C. A. (1986). The biology of natural transformation. Annual Review of Microbiology 40, 211-235.

StewarT, G. J. \& CYR, D. H. (1987). Distribution of natural transformation ability among marine bacteria (abstract no. $22 \mathrm{~A}-04$ $1435 \mathrm{H})$. EOS 68, 1712.

Stewart, G. J. \& Sinigalliano, C. D. (1990). Detection of horizontal gene transfer by natural transformation in native and introduced species of bacteria in marine and synthetic sediments. Applied and Environmental Microbiology 56, 1818-1824.

Tomasz, A. \& Hotchkiss, R. D. (1964). Regulation of the transformability of pneumococcal cultures by macromolecular cell products. Proceedings of the National Academy of Sciences of the United States of America 51, 480-487.

Trevors, J. T. \& Oddie, K. M. (1986). R-plasmid transfer in soil and water. Canadian Journal of Microbiology 32, 610-613.

VanElsas, J. D., Nikkel, M. \& VaN Overbeek, L. S. (1989). Detection of plasmid RP4 transfer in soil and rhizosphere, and the occurrence of homology to RP4 in soil bacteria. Current Microbiology 19, 375-381.

ZAR, J. H. (1984). Biostatistical Analysis, pp. 162-209. New Jersey: Prentice Hall.

Zervos, P. H., Morris, L. M. \& HellwiG, R. J. (1988). A novel method for rapid isolation of plasmid DNA. BioTechniques 6, 238-242. 